\title{
Soil development at Kongsfjorden, Spitsbergen
}

\author{
D. H. MANN, R. S. SLETTEN AND F. C. UGOLINI
}

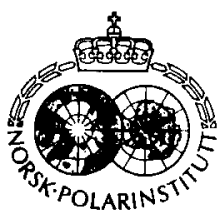

\begin{abstract}
Mann, D. H., Sletten, R. S. \& Ugolini, F.C. 1986: Soil development at Kongsfjorden, Spitsbergen. Polar Research 4 n.s. , 1-16.

Soils at well-drained sites near Kongsfjorden, Spitsbergen, are described in terms of morphology as well as solid and solution phase chemistry. Decarbonation is the dominant soil process and results in high $\mathrm{Mg}$ and $\mathrm{Ca}$ concentrations in soil solutions, in negative enrichment of $\mathrm{Fe}, \mathrm{Al}$, and non-carbonate clasts in nearsurface horizons, and in the accumulation of dolomitic silt horizons at depth. Coatings of reprecipitated carbonates extend into the $\mathrm{C}$ horizon. Several developmental pathways are suggested for well-drained carbonate soils at Kongsfjorden. In vegetation-rich areas, with calcite-rich parent material, relatively rapid $(\approx 10,000$ years) carbonate dissolution precedes silicate mineral weathering. In areas of Polar Desert climate and dolomitic parent material, decarbonation is slower and the continued accumulation of dolomite silt may eventually transform the soil system to a periglacial one.
\end{abstract}

D. H. Mann and F. C. Ugolini, College of Forest Resources and Quaternary Research Center, University of Washington, Seattle, Wash. 98195, USA; R. S. Sletten, Department of Environmental Engineering, $A R$ 10, University of Washington, Seattle, Wash, 98195, USA.

\section{Introduction}

As in much of the High Arctic, the bedrock of Svalbard is predominantly carbonate (Orvin 1940; Tedrow 1978). Although chemical weathering of carbonate rock there is widespread and rapid enough to comprise an important geomorphological agent (Akerman 1983; Salvigsen et al. 1983), previous soil studies tend to stress the high degree of periglacial disturbance on the landscape and the prevalence of physical over chemical weathering (Smith 1956; Federoff 1966; Jahn 1967; Fitzpatrick 1960). Nonetheless, decarbonation and iron reduction are noted in the earliest analyses of soil samples from Svalbard by Blanck (1919) and Meinardus (1930), while Szerszen's (1968) work in the Hornsund region shows that decarbonation of surface horizons is a widespread process.

In recent studies in the Kongsfjord area of Spitsbergen, van Vliet-Lanoe (1983) describes both 'sols bruns acides' and 'sols bruns calcaires' which, in some well-drained profiles, contain more than $2 \%$ free iron oxides. She also notes the occurrence of vesicular silt horizons and of secondary carbonate coatings that she relates to decarbonation of surface horizons.

Forman \& Miller (1984) describe a soil chronosequence developed on raised beach ridges on Brøggerhalvøya near Kongsfjorden that ranges in age from early Holocene to, possibly, penultimate interglacial times. They note that silt accumulation and secondary carbonate coatings are the dominant features of these soils and attempt to relate these to soil age. Like van Vliet-Lanoe (1983), they propose that silt horizons originate from partial dissolution of carbonate parent material with frost and hydration shattering comprising a secondary source of silt. Unlike most authors, Forman \& Miller (1984) suggest that frost thrusting actually abets soil development by replenishing surface horizons with weatherable, carbonate material.

The present report concerns the morphology and chemistry of soils developed on carbonaterich parent material on raised beach ridges in the Kongsfjorden area of Spitsbergen. Results demonstrate the importance of carbonate dissolution in soil genesis and provide suggestions regarding both the rates of soil formation and the developmental pathways of Spitsbergen soils.

\section{Description of the study area}

Bedrock on the north shore of Kongsfjorden consists of limestone, marble, mica schist, and quartzite (Hjelle 1974; Hjelle \& Lauritzen 1982). On Brøggerhalvøya, which forms the southern shore of Kongsfjorden (Fig. 1), bedrock is largely car- 


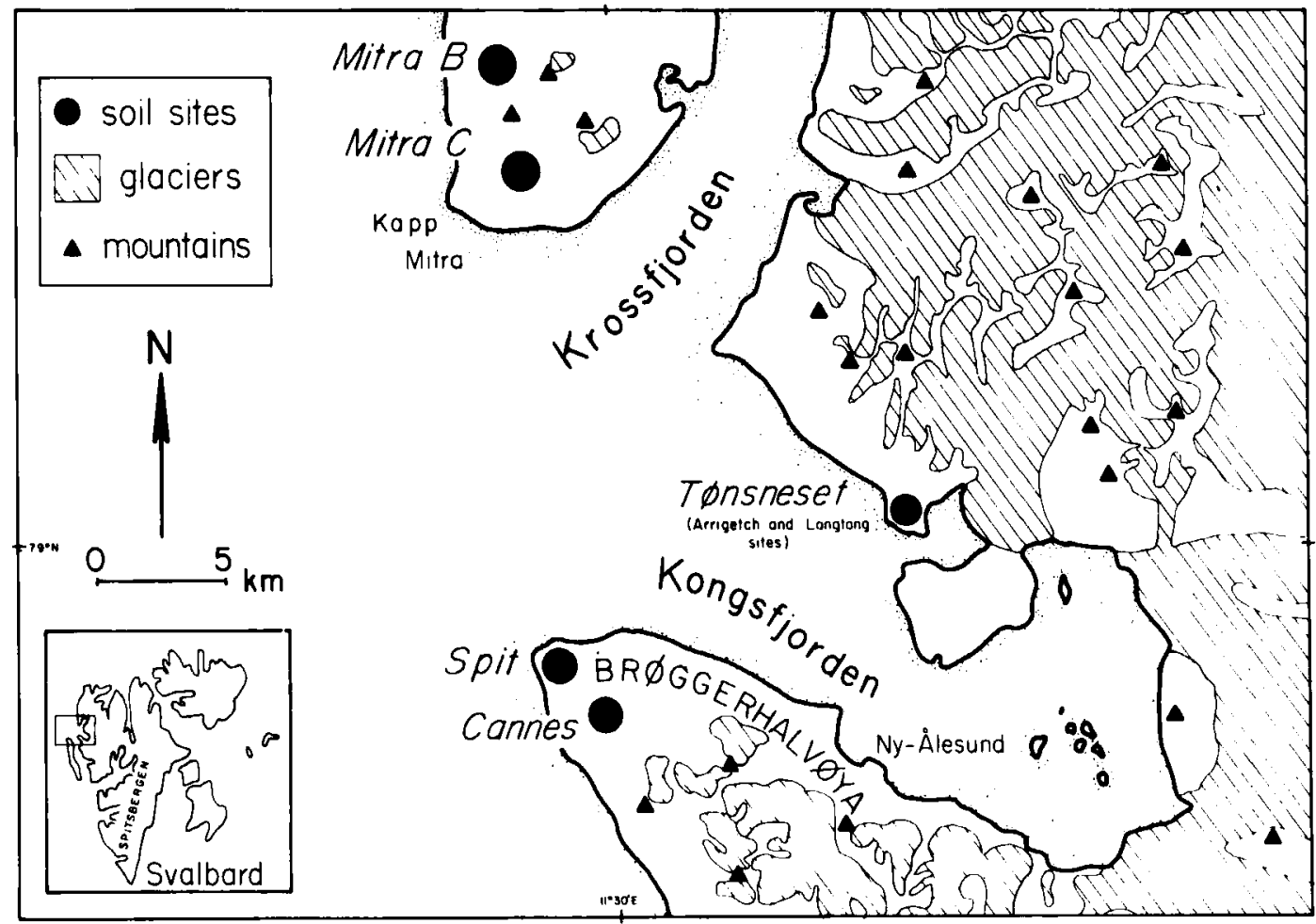

Fig. 1. Location of the study area. Soil sites shown by black circles.

bonate rock with dolomite the primary lithology on the outer peninsula (Challinor 1967; Hjelle \& Lauritzen 1982).

A marked vegetation zonation occurs in Kongsfjorden following the general pattern described by Summerhayes \& Elton (1928). Polar Desert, or Barren Zone vegetation occupies outer Brøggerhalvøya and Kapp Mitra, Dryas Zone vegetation occurs from approximately $\mathrm{Ny}$-Ålesund and Tønsneset seaward to these outer capes, Cassiope Zone vegetation exists inland of the Dryas Zone to the fjord head where the relatively lush Inner Fjord Zone vegetation occurs (Polunin 1945; Rønning 1965a; Elvebakk 1979; Brattbakk 1981).

Soils of four sites, three in the Barren Zone (Polar Desert) and one in the Cassiope Zone, were examined in detail. In the Cassiope Zone, two profiles were studied at Tønsneset on the north side of Kongsfjorden (Fig. 1). Geomorphology at Tønsneset consists of a flight of postLate Weichselian raised beaches overlying limestone bedrock and displaying large diameter, nonsorted polygons. Vegetation of the Arrigetch site at Tønsneset is a lichen-heath Tetragano-Dryadion (Rønning 1965b) consisting of a mosaic of Cassiope tetragona clumps interspersed with the lichens Cetraria delisei and, less commonly, Cetraria islandica. Other prominent plant species are Salix polaris, Polygonum viviparum, and Dryas octopetala. At the Arrigetch site, in ten, one-square-metre plots, Cassiope tetragona and Cetraria spp. comprise approximately $26 \%$ and $32 \%$, respectively, of the total plant cover. Total plant cover varies between $60 \%$ and $90 \%$ in these ten plots.

The Langtang site, also at Tønsneset, is located $100 \mathrm{~m}$ east of the Arrigetch site. Vegetation cover is $100 \%$, dominated by Cetraria delisei with $10 \%$ to $20 \%$, Salix polaris and Saxifraga oppositifolia growing within the continuous lichen mat.

In the Polar Desert, the Cannes site is located at the northwest tip of Brøggerhalvøya, $2.5 \mathrm{~km}$ from the sea; the Spit site is located on the extreme tip of the peninsula $75 \mathrm{~m}$ from the sea (Fig. 1). Vegetation at Cannes is typical of Polar Desert vegetation on Spitsbergen, consisting of plant cover less than $10 \%$ with Saxifraga oppo- 
sitifolia the most abundant species and the most important in terms of cover. Other species present are Salix polaris, Saxifraga cespitosa, Polygonum viviparum, Draba spp., and mosses. Foliose lichens are absent, and crustose lichens are relatively scarce at this site. Periglacial features are poorly developed, consisting of poorly sorted polygonal nets, 0.25 to $1 \mathrm{~m}$ in diameter. The Spit site is slightly richer in vegetation than Cannes, having up to $20 \%$ plant cover, again dominated by Saxifraga oppositifolia with minor $S$. cespitosa and Salix polaris, in addition to occasional individuals of Cerastium arcticum and Cetraria delisei.

Also in the Polar Desert, the Mitra B site is located on Kapp Mitra at the crest of the highest post-glacial raised beach, approximately $2 \mathrm{~km}$ from the sea (Fig. 1). Vegetation cover is less than $20 \%$, consisting of Saxifraga oppositifolia, crustose lichens, and Salix polaris. Periglacial features consist of occasional, poorly sorted nets. The Mitra $\mathrm{C}$ site is located several kilometres southeast of Mitra B on a slightly lower beach ridge with similar vegetation and drainage.

Mean annual temperature at $\mathrm{Ny}-\AA \AA$ lesund is $-5.8^{\circ} \mathrm{C}$, while mean monthly temperatures during the snowfree months of June, July and August are $2.1^{\circ} \mathrm{C}, 5.2^{\circ} \mathrm{C}$, and $4^{\circ} \mathrm{C}$, respectively (Steffensen 1982). Soil temperatures measured in the root layer of a Dryas community over 13 days in midAugust 1965 varied between $0.5^{\circ} \mathrm{C}$ and $10^{\circ} \mathrm{C}$, with most temperatures between $2^{\circ} \mathrm{C}$ and $6^{\circ} \mathrm{C}$ (Rønning 1965a). Precipitation at $\mathrm{Ny}$-Ålesund averages $385 \mathrm{~mm} /$ year, and falls mainly in the winter as snow.

\section{Materials and methods}

Profiles were described by standard methods (Soil Survey Staff 1962, 1975, 1981) using the most recent nomenclature (Guthrie \& Witty 1982). Lysimeters consist of $12-15 \mu \mathrm{m}$ porous Mullite discs mounted in nylon bases. Soil solutions are drawn under a 0.1 atmosphere vacuum (Ugolini et al. 1982). Because of the dry summer climate, percolation was induced by irrigation of the soil above the lysimeters using either dionized water or melting snow. Irrigation is calculated to be equivalent to 15 to $30 \mathrm{~mm}$ of rainfall over 2 to 4 days. These amounts are within the range of maximum precipitation recorded within 24 hours at Ny-Ålesund (Steffensen 1982).

Electrical conductivity, $\mathrm{pH}$, and alkalinity were determined on lysimetry solutions in the field. Subsamples for laboratory analysis were filtered at $0.22 \mu \mathrm{m}$ and one subsample was acidified with $\mathrm{HNO}_{3}$ and kept for analysis of major cations using a Jarrel-Ash Model 96-955 inductively coupled argon plasma spectrophotometer (ICP). Another subsample was preserved with $\mathrm{CH}_{3} \mathrm{CN}$ and later analysed for inorganic anions on a Dionex Model 2010 ion chromatograph.

Total nitrogen and phosphorus were determined on soil samples digested with $\mathrm{Li}_{2} \mathrm{SO}_{4}$, $\mathrm{H}_{2} \mathrm{SO}_{4}$, and $\mathrm{H}_{2} \mathrm{O}_{2}$ in a modified Kjeldahl procedure (Parkinson \& Allen 1975) and measured colourimetrically on a Technicon Autoanalyzer II. Soil $\mathrm{pH}$ was measured in a $1: 2$ soil: water mixture and electrical conductivity in a $1: 5$ mixture.

Organic carbon was determined by the modified Walkley-Black procedure (Allison 1965). Fe and $\mathrm{Al}$ were extracted using dithionite (Jackson 1969), pyrophosphate (McKeague 1967), and oxalate (Jackson 1969) procedures and measured on the ICP.

Samples for X-ray diffraction were ground to pass a 140 mesh sieve, prepared as powder mounts, and $\mathrm{X}$-rayed using a Picker unit with $\mathrm{Cu}$ $\mathrm{K} \alpha$ radiation and a $\mathrm{Ni}$ filter. Particle size was determined by dry sieving the $<2 \mathrm{~mm}$ fraction down to the $0.05 \mathrm{~mm}$ size. The silt and clay fractions $(<0.05 \mathrm{~mm})$ were dispersed in $0.5 \%$ sodium hexametaphosphate and analysed with a SediGraph 500D particle size analyser.

Total carbonates were determined by direct measurement of $\mathrm{CO}_{2}$ released during dissolution in 2 molar $\mathrm{HCl}$ of a sample ground to pass a 100 mesh sieve (Bundy \& Bremner 1972). Evolved $\mathrm{CO}_{2}$ was captured in a 2 molar $\mathrm{KOH}$ trap and back-titrated with standard $\mathrm{HCl} . \mathrm{CO}_{2}$ evolved during this procedure is equal to carbonates present in the sample. $\mathrm{Ca}, \mathrm{Mg}, \mathrm{Al}$, and Fe released by acid dissolution in the latter procedure were assayed on the ICP. All $\mathrm{Ca}$ and $\mathrm{Mg}$ present is assumed to be in the form of carbonates. From the $\mathrm{Ca}$ and $\mathrm{Mg}$ data, we first reconstitute dolomite by assuming a $\mathrm{Ca} / \mathrm{Mg}$ ratio of 1 and calculate a percent $\mathrm{CaMg}\left(\mathrm{CO}_{3}\right)_{2}$ equivalent. The remaining $\mathrm{Ca}$ is presumed to exist as $\mathrm{CaCO}_{3}$ (calcite).

All ${ }^{14} \mathrm{C}$ dates on shells were first normalized to -25 per mil ${ }^{13} \mathrm{C}$ and then corrected for the oceanic reservoir effect by subtracting 510 years (Mangerud \& Gulliksen 1975). Whale bone dates were corrected by subtracting 450 years from the ${ }^{13} \mathrm{C}$ ( -25 per mil) adjusted date. 


\section{Results}

\section{Soil ages}

Radiocarbon dates on whale bone and shell fragments found near or in the soil pits provide minimum limiting dates on the initiation of soil development at the different sites. On Brøggerhalvøya, shells from the Spit Site profile dated to $9890 \pm 290$ years B.P. (GX-9894). Whale bone, from an altitude of $36 \mathrm{~m}$ associated with the beach ridge where the Cannes Site is located, dated to $11,750 \pm 430$ years B.P. (GX-9909). At Tønsneset the ages of the Arrigetch and Langtang Sites were bracketed by a ${ }^{14} \mathrm{C}$ date of $10,000 \pm 170$ years B.P. (GX-10,104) on shell and barnacle fragments and a date of $9440 \pm 360$ years B.P. (GX-9898). At Kapp Mitra, a whale rib several metres below the altitude of the Mitra B soil pit yielded a date of $10,320 \pm 330$ years B.P. (GX$10,103)$. Together, these radiocarbon dates indicate that surfaces at all the sites stabilized about the same time in early post-glacial times and that the soils described here are all of a 9,000 to 12,000 years B.P. age.

\section{Soil morphology}

Soils developed in the Polar Desert environments of Brøggerhalvøya and Kapp Mitra are markedly different in morphology from the soils of Tønsneset developed in the Cassiope Zone (Appendix I). Soils of the three Polar Desert sites possess a well-developed desert pavement 6 to $8 \mathrm{~cm}$ thick composed largely of angular pebbles and usually double layered with an upper, coarser layer overlying a sandier layer 1 to $3 \mathrm{~cm}$ thick. Soils in the Cassiope Zone lack a desert pavement, having instead an $\mathrm{Oi} / \mathrm{Oe}$ horizon consisting of plant litter.

Although the Polar Desert profiles, Cannes and Mitra C. possess a weak A horizon, the A horizon is much better developed in Cassiope vegetation at Tønsneset. However, at Tønsneset, the Langtang profile differs from the Arrigetch by lacking an A horizon; instead, the Oe horizon directly overlies a cambic $\mathrm{Bw}$ horizon. This difference is probably caused by the fact that the Cetraria lichens dominating the vegetation cover of the Langtang profile lack root systems penetrating more than several centimetres below the surface and, hence, little mixing of organic material and mineral soil occurs.

The B horizon in the Polar Desert sites' soils is defined primarily by silt accumulation and secondarily by colour. We follow the notation proposed by Forman \& Miller (1984) using the small letter ' $l$ ' to indicate a horizon of silt accumulation. Hence the Polar Desert profiles all possess Bwl horizons as their master $B$ horizons. In contrast, silt accumulation does not occur in the $\mathrm{Bw}$ horizon of Cassiope Zone soils at Tønsneset, however, staining due to iron oxidation is more evident in the Bw horizon there than at the Polar Desert Sites. Soil structure is most pronounced in the Bwl horizons of the Polar Desert soils where vesicular silt bridges clasts and forms dense caps up to several centimetres thick on the upper surfaces of stones. Less developed silt caps occur in $\mathrm{A}$ and $\mathrm{BC}$ horizons, as well as in some $\mathrm{C}$ horizons. Silt caps present on stones in the Cassiope Zone soils at Tønsneset are thinner, less extensive, and do not bridge clasts.

Coatings of secondary calcium carbonate minerals occur on rocks in the lower horizons of the profiles of all sites. These coatings range in form from thin platelets to centimetre-thick pendant forms. They are present predominantly on the underside of stones. Carbonate coatings occasionally occur on the bottom of surface stones, but are usually less developed. Coatings are rare at Tønsneset above the $\mathrm{C}$ horizon but are abundant at the other sites as high as the Bw horizon.

\section{Pebble lithologies}

Carbonate rocks are a major component of the parent material of all the soils studied, comprising up to $83 \%$ of the pebbles $(>0.5 \mathrm{~cm},<5 \mathrm{~cm})$ in the $C$ horizon of soils on Brøggerhalvøya and up to $50 \%$ on Kapp Mitra and Tønsneset (Fig. 4). $\mathrm{X}$-ray diffraction reveals that dolomite is the dominant lithology at the Cannes site with a minor calcite component. At Tønsneset $\mathrm{X}$-ray diffraction indicates that calcite is the predominant carbonate mineral in pebbles and dolomite is a minor component.

The high frequency of dissolution morphologies on carbonate clasts in the desert pavements of the Polar Desert sites provides an immediate clue to the importance of decalcification in Kongsfjorden soils. Pebble counts reveal the extent of this process by showing that near-surface horizons in all profiles are depleted in carbonate pebbles relative to the lower horizons (Fig. 2). This trend is most striking at Tønsneset, where carbonate pebbles are lacking entirely from the $\mathrm{A}$ horizon. Dis- 


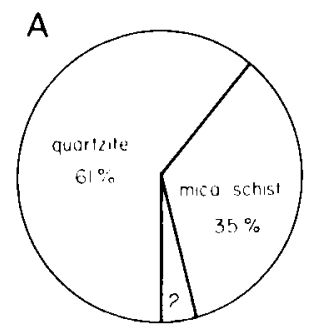

Arrigetch Site

A

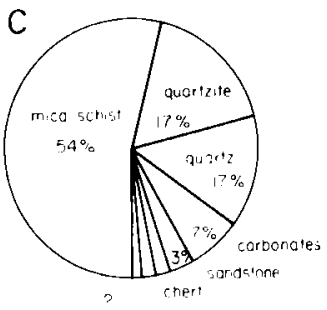

und it metamarnics

Mitro C Site

Desert Pavement

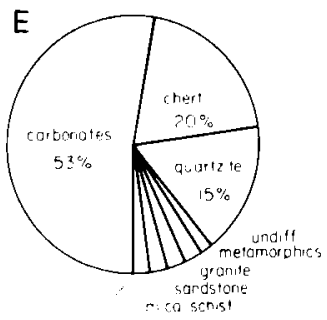

Connes Site I

Desert Povement

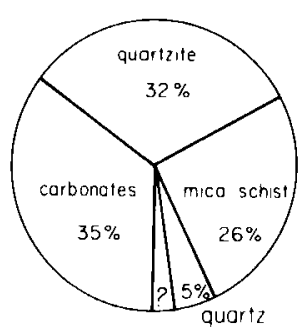

Arrigetch Site C

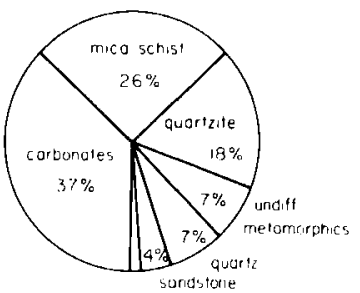

sheil

Mitra C Site

$B C$

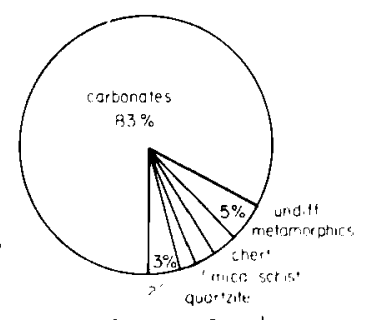

Cannes Site I

C

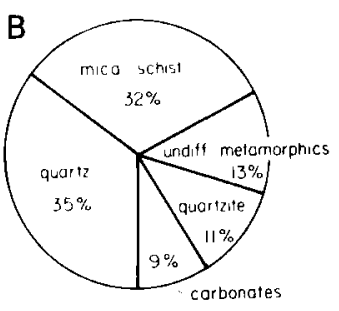

Mitra B Site

Desert Povement

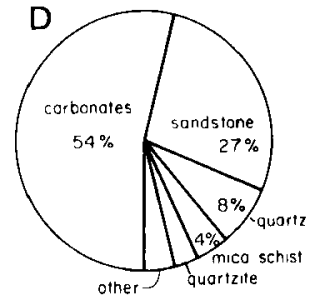

Spit Site

Desert Pavement

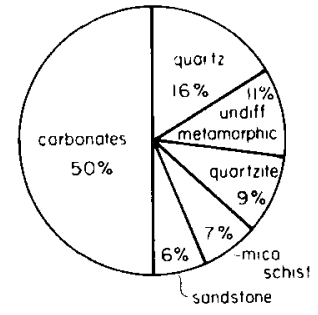

Mitra B Site

$B C$

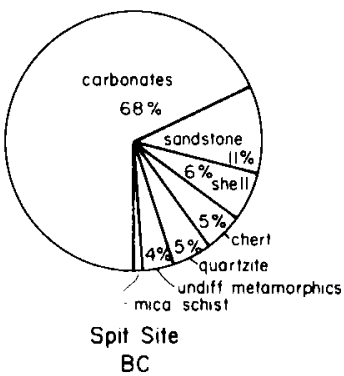

$\mathrm{BC}$

Fig. 2. Pebble counts from soil profiles at Kongsfjorden, Spitsbergen. Sample size varies between 50 and 200 pebbles.

appearance of carbonate rocks in the near-surface horizons is accompanied by negative enrichment of non-carbonate lithologies in all profiles.

\section{Particle size in the $<2 \mathrm{~mm}$ fraction}

The three Polar Dessert profiles all have welldeveloped silt horizons (Table 1). These Bwl horizons are approximately $20 \%$ to $30 \%$ silt with medium silt $(10-25 \mu \mathrm{m})$ comprising the majority of this size fraction (Table 2). Clay is scarce in the silt horizons, comprising less than $2 \%$ of the total $<2 \mathrm{~mm}$ fraction. The two Tønsneset profiles lack silt horizons entirely.

\section{Total carbonates in the $<2 \mathrm{~mm}$ fraction}

Paralleling the near-surface depletion of carbonate pebbles, marked near-surface depletion

occurs of total carbonate in the $<2 \mathrm{~mm}$ fraction in all the profiles, being most pronounced at Tønsneset (Fig. 3). There, in the Arrigetch profile, carbonates are absent from the $A$ and Bw horizons but increase to approximately $28 \%$ $\mathrm{CaCO}_{3}$ equivalent in the $\mathrm{C}$ horizon. The Langtang profile is similar but more deeply leached.

In both the Spit and Mitra $C$ profiles, carbonate content decreases with depth through the Bwl horizon. In contrast, the Mitra B and Cannes profiles show slight carbonate peaks in the Bwl horizon (Fig. 3). The highest weight percentage of total carbonate is reached in the Cannes site, Profile 2, with $7.78 \mathrm{mmol} / \mathrm{g} \mathrm{CO}_{3}$, which is equivalent to approximately $78 \%$ calcium carbonate.

The sites can be arranged along a gradient of degree of carbonate leaching on the basis of the shapes of their total carbonate/depth curves. The 
Table 1. Particle size in the $<2 \mathrm{~mm}$ fraction as percent air dry weight of soils near Kongsfjorden, Spitsbergen.

\begin{tabular}{|c|c|c|c|c|c|c|c|}
\hline \multirow[b]{2}{*}{ Profile } & \multirow[b]{2}{*}{ Horizon } & \multicolumn{6}{|c|}{ Particle sizes (mm) } \\
\hline & & $1-2$ & $1-0.5$ & $0.5-0.25$ & $0.25-0.1$ & $0.1-0.05$ & $<0.05$ \\
\hline & & $\%$ & $\%$ & $\%$ & $\%$ & $\%$ & $\%$ \\
\hline \multirow[t]{6}{*}{ Cannes } & Desert pavement & 67 & 24 & 2 & 2 & 4 & 1 \\
\hline & A & 34 & 34 & 8 & 6 & 8 & 9 \\
\hline & Bwl $(9-13 \mathrm{~cm})$ & 35 & 21 & 2 & 4 & 11 & 26 \\
\hline & Bwl $(18-22 \mathrm{~cm})$ & 47 & 14 & 4 & 4 & 9 & 22 \\
\hline & $\mathrm{BC}$ & 54 & 30 & 5 & 2 & 2 & 7 \\
\hline & $\mathrm{C}$ & 67 & 20 & 3 & 2 & 2 & 6 \\
\hline \multirow[t]{4}{*}{ Spit } & Desert pavement & 28 & 36 & 17 & 10 & 9 & 0.2 \\
\hline & $\mathrm{Bwl}$ & 31 & 10 & 6 & 10 & 12 & 30 \\
\hline & $\mathrm{BC}$ & 42 & 40 & 7 & 2 & 2 & 6 \\
\hline & $\mathrm{BC} / \mathrm{C}$ & 82 & 8 & 2 & 2 & 2 & 5 \\
\hline \multirow[t]{4}{*}{ Mitra B } & Upper desert pavement & 0 & 27 & 27 & 19 & 23 & 4 \\
\hline & Lower desert pavement & 58 & 24 & 9 & 8 & 1 & 0.5 \\
\hline & Bwl & 8 & 5 & 4 & 19 & 31 & 32 \\
\hline & $\mathrm{BC}$ & 44 & 20 & 10 & 11 & 8 & 7 \\
\hline \multirow[t]{4}{*}{ Arrigetch } & A & 21 & 40 & 17 & 11 & 7 & 4 \\
\hline & $\mathrm{Bw}$ & 20 & 48 & 19 & 7 & 3 & 2 \\
\hline & $\mathrm{BC}$ & 19 & 49 & 23 & 3 & 3 & 3 \\
\hline & $\mathrm{C}$ & 42 & 42 & 10 & 2.5 & 1.2 & 1.6 \\
\hline \multirow[t]{4}{*}{ Langtang } & A & 16 & 23 & 21 & 18 & 13 & 8 \\
\hline & Bw & 13 & 34 & 31 & 13 & 0.4 & 9 \\
\hline & $\mathrm{BC}$ & 42 & 46 & 6 & 2 & 1 & 3 \\
\hline & $\mathrm{C}$ & 80 & 19 & 0.6 & 0.5 & 0.6 & 0.1 \\
\hline
\end{tabular}

Tønsneset soils are mostly deeply leached followed by the Spit/Mitra $\mathrm{C}$ sites, and then the Mitra B/Cannes sites.

\section{Identity of the carbonate in the $<2 \mathrm{~mm}$ fraction}

In the Tønsneset profiles, most of the carbonate in the $\mathrm{C}$ horizon is calcite with only minor dolomite present (Fig. 4). In contrast, in the Mitra B profile, dolomite is the predominant carbonate with only minor calcite present. Also in the Brøggerhalvøya profiles, dolomite is the predominant carbonate mineral in the $<2 \mathrm{~mm}$ fraction of all horizons, but the minor calcite component increases with depth below the Bwl horizon. Given the scarcity of primary calcite in the dolomitic parent material of Brøggerhalvøya and the abundance of carbonate coatings on clasts in the lower horizons, most of this calcite is probably derived from secondary coatings.

The silt horizon at Cannes is primarily dolomite (Table 3, Fig. 4). The highest percent carbonates in the Cannes silt horizon occurs in the $<0.05 \mathrm{~mm}$ (silt and clay) and the $0.10-0.05 \mathrm{~mm}$ (very fine

Table 2. Particle size of the $<0.05 \mathrm{~mm}$ fraction of Bw horizons of Kongsfjorden, Spitsbergen, soils expressed as percent of total $<2 \mathrm{~mm}$ fraction weight.

\begin{tabular}{|c|c|c|c|c|c|}
\hline & $\begin{array}{c}(25-50 \mu \mathrm{m}) \\
\text { course silt }\end{array}$ & $\begin{array}{l}(10-25 \mu \mathrm{m}) \\
\text { medium silt }\end{array}$ & $\begin{array}{c}(2-10 \mu \mathrm{m}) \\
\text { finc silt }\end{array}$ & $(<2 \mu \mathrm{m})$ clay & $\begin{array}{c}\text { Total } \\
<50 \mu \mathrm{m} \\
\text { silt and clay }\end{array}$ \\
\hline & $\%$ & $\%$ & $\%$ & $\%$ & $\%$ \\
\hline Cannes Bwl 9-13 cm & 7.2 & 12.2 & 5.2 & 1.3 & 25.9 \\
\hline Cannes Bwl $18-22 \mathrm{~cm}$ & 3.9 & 11.0 & 5.8 & 0.9 & 21.6 \\
\hline Spit Bwl & 4.8 & 17.0 & 7.5 & 0.9 & 30.2 \\
\hline Mitra Bwl & 9.4 & 13.6 & 8.1 & 1.3 & 32.4 \\
\hline
\end{tabular}


A
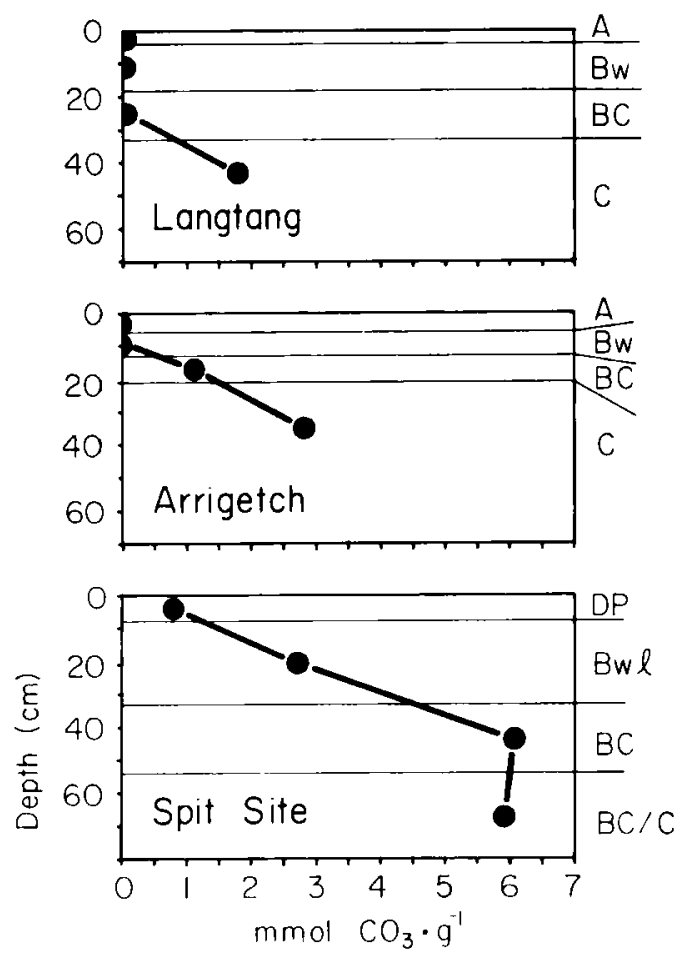

B
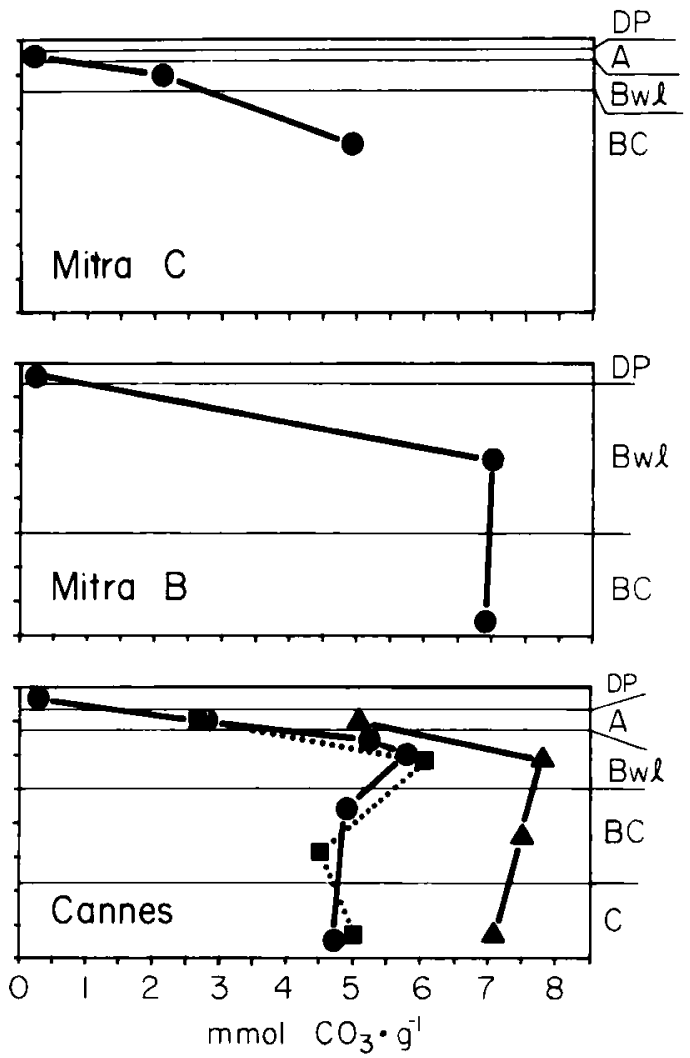

Fig. 3. Total carbonates in the less than $2 \mathrm{~mm}$ size fraction from soils at Kongsfjorden. Spitsbergen. Different symbols in the Cannes sitc graph represent each of three different profiles.

Table 3. Detcrmination of carbonates by two methods in different size fractions from the Cannes Bwl horizon (9 to $13 \mathrm{~cm})$. Kongsfjorden, Spitsbergen.

\begin{tabular}{|c|c|c|c|c|c|c|}
\hline \multirow{2}{*}{$\begin{array}{l}\text { Sizc } \\
\text { fraction } \\
(\mathbf{m m})\end{array}$} & \multicolumn{2}{|c|}{$\begin{array}{c}\mathrm{CO}_{2} \text { evolution upon } \\
\text { and dissolution }\end{array}$} & \multicolumn{4}{|c|}{$\mathrm{Ca}$ and $\mathrm{Mg}$ released upon dissolution } \\
\hline & $\mathrm{mmol} \mathrm{CO}_{3} \mathrm{~g}^{-1}$ & $\begin{array}{l}\% \mathrm{CaCO}_{3} \\
\text { equivalent }\end{array}$ & $\mathrm{mmol} \mathrm{Ca} \mathrm{g-1}$ & $\begin{array}{l}\% \mathrm{CaCO}_{3} \\
\text { equivalent }\end{array}$ & $\mathrm{mmol} \mathrm{Mg} \mathrm{g}^{-1}$ & $\begin{array}{l}\% \mathrm{CaMg}\left(\mathrm{CO}_{3}\right)_{2} \\
\text { equivalent }\end{array}$ \\
\hline $1-2$ & 3.60 & 36.0 & 2.24 & 5.2 & 1.72 & 31.6 \\
\hline $0.5-1$ & 3.13 & 31.3 & 1.85 & 4.2 & 1.43 & 26.3 \\
\hline $0.25-0.5$ & 2.79 & 27.9 & 1.75 & 3.8 & 1.37 & 25.2 \\
\hline $0.105-0.25$ & 2.82 & 28.2 & 1.65 & 3.5 & 1.30 & 23.9 \\
\hline $0.05-0.105$ & 6.76 & 67.6 & 3.58 & 2.1 & 3.37 & 62.0 \\
\hline$<0.05$ & 7.38 & 73.8 & 3.65 & 1.6 & 3.49 & 64.2 \\
\hline \multicolumn{7}{|l|}{ Combined } \\
\hline$<2 \mathrm{~mm}$ & 5.30 & 53.0 & & & & \\
\hline
\end{tabular}


A
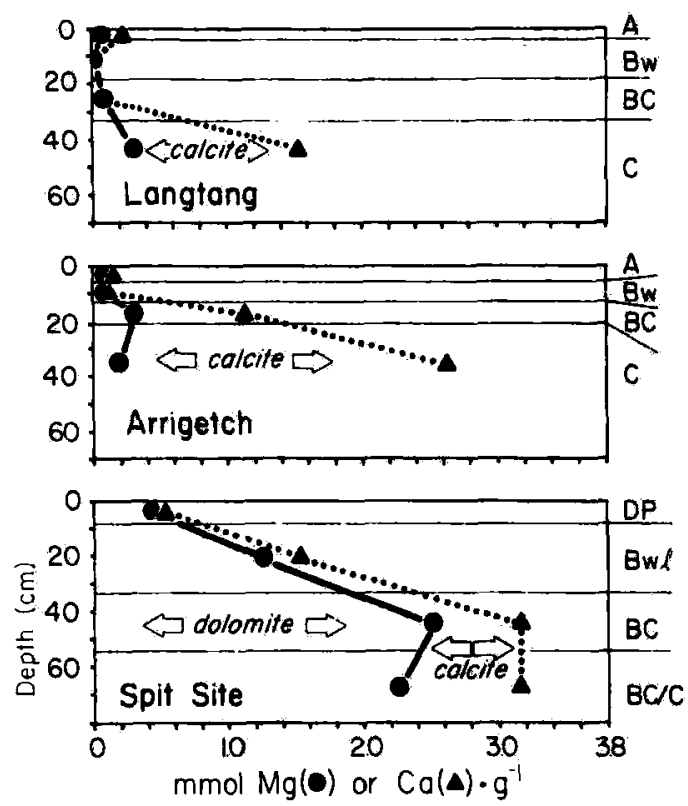

B
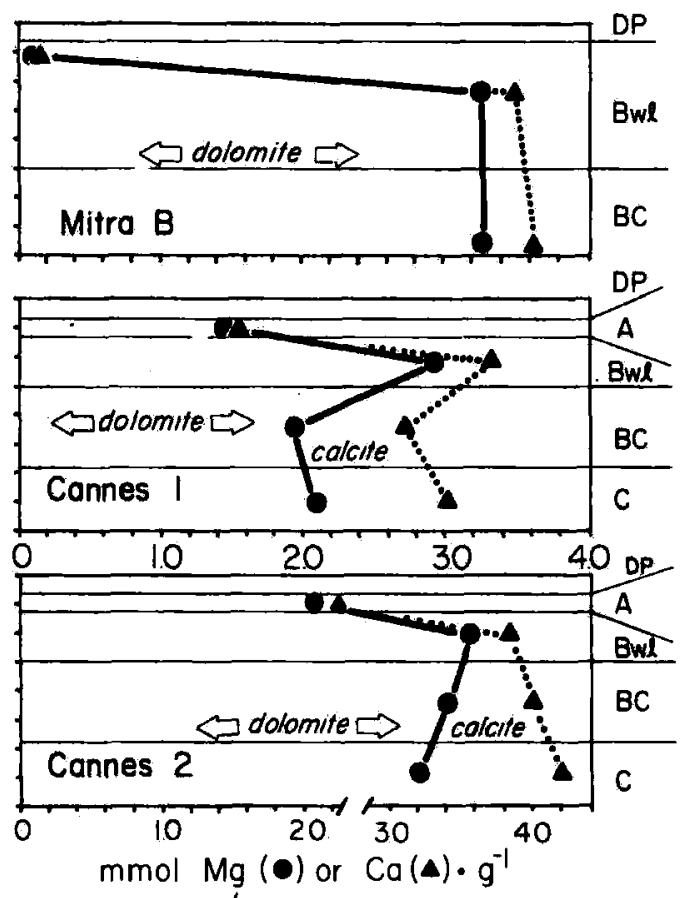

Fig. 4. Soil carbonates from Kongsfjorden, Spitsbergen, differentiated into dolomite and calcite components. Circles represent $\mathrm{Mg}$ and triangles, $\mathrm{Ca}$.

sand) size fractions with up to $81 \% \mathrm{CaCO}_{3}$ equivalent present (Fig. 5). In all size fractions of the $9-13 \mathrm{~cm}$ sample, most of the carbonate is in the form of dolomite (Fig. 5).

Organic matter, iron, aluminium, nitrogen and phosphorus

Organic matter accumulation is greatest in the Cassiope zone in the Tonsneset profiles (Table 4). The Spit profile ranks next in total organic matter content followed by the Mitra profiles and finally by Cannes.

Dithionite-extractable $\mathrm{Fe}$ is low in all the profiles studied, reaching highest values of $0.5 \%$ to $1.0 \%$ in several Bw horizons (Table 5). Aluminium is less abundant than iron, reaching high values between $0.03 \%$ and $0.08 \%$ in most $\mathrm{Bw}$ horizons; the Mitra $\mathrm{C}$ site is unusual in having aluminium values up to $0.6 \%$ in the $\mathrm{A}$ horizon. Pyrophosphate extractable $\mathrm{Al}$ and $\mathrm{Fe}$ is highest, up to about $0.04 \%$ and $0.07 \%$ respectively, in the
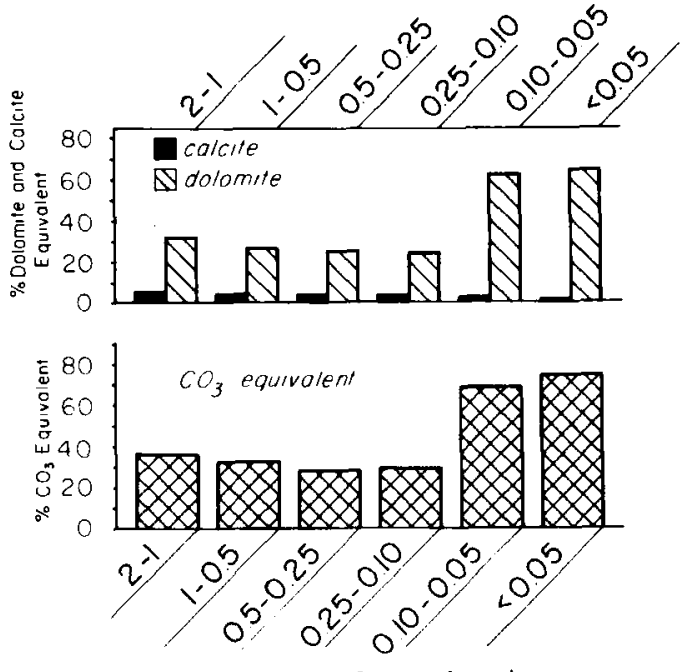

Particle Size Class $(\mathrm{mm})$

Fig. 5. Carbonate content and composition in different size fractions from 9 to $13 \mathrm{~cm}$ depth in the Bwl horizon of the Cannes profile, Kongsfjorden, Spitsbergen. 
Table 4. Electrical conductivity, pH, organic carbon, nitrogen, and phosphorus in Kongsfjorden soils. Western Spitsbergen.

\begin{tabular}{|c|c|c|c|c|c|c|}
\hline Profile & Horizon & $\begin{array}{l}\mathrm{EC}(\mu S) \\
(1: 5)\end{array}$ & $\begin{array}{l}\mathrm{pH} \\
(1: 2)\end{array}$ & $\begin{array}{l}\text { Organic } \\
\text { matter }\end{array}$ & $\mathbf{N}$ & $P$ \\
\hline & & & & $\%$ & $\%$ & $\%$ \\
\hline \multirow[t]{5}{*}{ Cannes } & Desert pavement & - & - & - & 0.14 & 0.12 \\
\hline & A & 55.4 & 7.90 & 1.3 & 0.11 & 0.09 \\
\hline & Bwl & 47.2 & 8.33 & 0.9 & 0.09 & 0.10 \\
\hline & $\mathrm{BC}$ & 43.3 & 8.20 & 0.1 & 0.04 & 0.08 \\
\hline & $\mathrm{C}$ & 41.8 & 8.13 & 0.1 & 0.04 & 0.09 \\
\hline \multirow[t]{4}{*}{ Spit } & Desert pavement & 43.7 & 6.90 & 1.7 & 0.35 & 0.06 \\
\hline & Bwl & 63.3 & 8.07 & 3.8 & 0.27 & 0.11 \\
\hline & $\mathrm{BC}$ & 43.1 & 7.93 & 0.4 & 0.10 & 0.06 \\
\hline & $\mathrm{BC} / \mathrm{C}$ & 47.2 & 7.23 & 0.3 & 0.16 & 0.11 \\
\hline \multirow[t]{4}{*}{ Mitra B } & Upper desert pavement & & & 2.1 & & \\
\hline & Lower desert pavement & & & 0.7 & & \\
\hline & Bwl & & & 2.4 & & \\
\hline & $\mathrm{BC}$ & & & 0.2 & & \\
\hline \multirow[t]{4}{*}{ Mitra C } & Desert pavement & & & 2.1 & & \\
\hline & A & & & 2.7 & & \\
\hline & $\mathrm{Bwl}$ & & & 1.8 & & \\
\hline & $\mathrm{BC}$ & & & 0.3 & & \\
\hline \multirow[t]{5}{*}{ Arrigetch } & $\mathrm{Oi} / \mathrm{Oe}$ & - & - & - & 0.87 & 0.13 \\
\hline & A & 68.7 & 6.18 & 7.4 & 0.14 & 0.04 \\
\hline & $\mathrm{Bw}$ & 15.1 & 7.88 & 1.0 & 0.06 & 0.04 \\
\hline & $\mathrm{BC}$ & 47.7 & 7.56 & 0.5 & 0.03 & 0.04 \\
\hline & $C$ & 52.9 & 7.75 & $<.1$ & 0.01 & 0.03 \\
\hline \multirow[t]{4}{*}{ Langtang } & $\mathrm{Oc}$ & 61.0 & 6.54 & 37.0 & - & - \\
\hline & $\mathrm{Bw}$ & 13.6 & 7.32 & 1.2 & 0.11 & 0.13 \\
\hline & $\mathrm{BC}$ & 13.5 & 7.28 & 0.2 & - & - \\
\hline & $\mathrm{C}$ & 41.7 & 7.26 & 0.1 & 0.03 & 0.09 \\
\hline
\end{tabular}

upper, most organic-rich A horizons at Tønsneset. Similar levels and trends occur in the Polar Desert profiles.

The nitrogen content of the Arrigetch, Cannes, and Spit site profiles ranges between $0.01 \%$ and $0.87 \%$ (Table 4 ). Phosphorus is roughly similar in the three profiles where it was determined ranging from $0.03 \%$ to $0.13 \%$. The Arrigetch profile tends to be slightly poorer in $\mathrm{P}$ than the Spit and Cannes profiles.

\section{Lysimetry}

Soil solutions extracted by tension lysimeters after artificial irrigation provide an idea of the solution chemistry of the Cannes and Arrigetch sites (Table 6, Fig. 6). At both sites solution composition reflects intense carbonate dissolution in progress. $\mathrm{Ca}$ and $\mathrm{Mg}$ dominate the cations in solution followed by $\mathrm{Na}$. Bicarbonate is the most abundant anion followed by lesser concentrations of chloride and sulphate. In the Arrigetch profile, ionic strength increases markedly with depth reflecting the already well-advanced decarbonation of the upper horizons (Table 6). At Cannes, ionic strength of the soil solution increases below the A horizon, sometimes peaking in the Bwl horizon. This peak in ions leaving the Bwl horizon may be an artifact caused by rapid percolation through the gravelly $\mathrm{C}$ horizon. Collections following slower irrigation by melting snow show a peak in ionic strength in the $\mathrm{C}$ horizon, rather than in the Bwl (Table 6; Fig. 6).

Groundwater collected above the permafrost table in the $\mathrm{C}$ horizon of the Cannes site yielded values similar in elemental composition to solutions generated by irrigation taken from similar depths (Table 6). Similarly, stream water collections from the Kvadehukelva on Brøggerhalvøya are comparable in ionic composition and 
Table 5. Dithionite, pyrophosphate, and oxalate extractable Fe and Al in Kongsfjorden soils, Western Spitsbergen.

\begin{tabular}{|c|c|c|c|c|c|c|c|}
\hline \multirow[b]{2}{*}{ Profile } & \multirow[b]{2}{*}{ Horizon } & \multicolumn{2}{|c|}{ Dithionite } & \multicolumn{2}{|c|}{ Pyrophosphate } & \multicolumn{2}{|c|}{ Oxalate } \\
\hline & & $\mathrm{Fe}$ & Al & $\mathrm{Fe}$ & Al & $\mathrm{Fe}$ & Al \\
\hline & & $\%$ & $\%$ & $\%$ & $\%$ & $\%$ & $\%$ \\
\hline \multirow[t]{5}{*}{ Cannes } & Desert pavement & 0.28 & 0.03 & - & - & - & - \\
\hline & A & 0.44 & 0.03 & 0.010 & 0.010 & - & - \\
\hline & Bwl & 0.37 & 0.03 & 0.008 & 0.011 & - & - \\
\hline & $\mathrm{BC}$ & 0.18 & 0.01 & 0.003 & $<0.002$ & - & - \\
\hline & $\mathrm{C}$ & 0.17 & 0.01 & 0.002 & $<0.002$ & - & - \\
\hline \multirow[t]{4}{*}{ Spit } & Desert pavement & 0.21 & 0.01 & 0.007 & $<0.002$ & - & - \\
\hline & Bwl & 0.60 & 0.04 & 0.051 & 0.034 & 一 & - \\
\hline & $\mathrm{BC}$ & 0.28 & 0.02 & 0.011 & 0.009 & - & - \\
\hline & $\mathrm{BC} / \mathrm{C}$ & 0.31 & 0.01 & 0.007 & 0.005 & - & - \\
\hline \multirow[t]{4}{*}{ Mitra B } & Upper desert pavement & - & - & 0.007 & 0.003 & - & - \\
\hline & Lower desert pavement & 0.45 & 0.12 & 0.023 & 0.006 & - & 一 \\
\hline & $\mathrm{Bwl}$ & 0.55 & 0.30 & 0.028 & 0.016 & - & - \\
\hline & $\mathrm{BC}$ & 0.15 & 0.04 & 0.008 & $<0.002$ & - & - \\
\hline \multirow[t]{4}{*}{ Mitra C } & Desert pavement & 0.22 & 0.05 & 0.012 & 0.003 & - & - \\
\hline & A & 1.05 & 0.60 & 0.053 & 0.031 & - & - \\
\hline & Bwl & 0.52 & 0.41 & 0.027 & 0.021 & - & - \\
\hline & $\mathrm{BC}$ & 0.06 & 0.04 & 0.003 & $<0.002$ & - & - \\
\hline \multirow[t]{4}{*}{ Arrigetch } & A & 0.55 & 0.06 & 0.055 & 0.025 & 0.27 & 0.14 \\
\hline & $\mathrm{Bw}$ & 0.71 & 0.06 & 0.061 & 0.026 & 0.24 & 0.12 \\
\hline & $\mathrm{BC}$ & 0.58 & 0.04 & 0.008 & $<0.002$ & 0.14 & 0.05 \\
\hline & $\mathrm{C}$ & 0.37 & 0.02 & 0.001 & $<0.002$ & 0.07 & 0.03 \\
\hline \multirow[t]{4}{*}{ Langtang } & A & 0.37 & 0.05 & 0.068 & 0.037 & 0.19 & 0.10 \\
\hline & $\mathrm{Bw}$ & 0.69 & 0.07 & 0.066 & 0.044 & 0.18 & 0.12 \\
\hline & $\mathrm{BC}$ & 0.56 & 0.04 & 0.007 & $<0.002$ & 0.09 & 0.04 \\
\hline & $\mathrm{C}$ & 0.34 & 0.02 & 0.003 & $<0.002$ & 0.09 & 0.04 \\
\hline
\end{tabular}

concentrations to irrigated soil solutions from the $\mathrm{C}$ horizons and reflect the intense dissolution in progress in the watershed (Table 6).

\section{Discussion}

According to Tedrow's (1977) classification, the soils in the Cassiope Zone at Tønsneset are Arctic Brown soils of the Subpolar Desert Zone, while those on Kapp Mitra and Brøggerhalvøya are Polar Desert soils of the Subpolar Desert Zone. These soils do not fit well into either the Classification System of Duchaufour (1982) for calcimagnesium soils or that of Soil Survey Staff (1975). Kongsfjorden soils are probably closest to Pergelic Cryumbrepts in the American classification system.

Regardless of their classification, dissolution of primary carbonate minerals is the dominant soil process occurring in well-drained soils of Kongsfjorden. This process is reflected in the enrichment of non-carbonate clasts in surface horizons (Fig. 2), the distribution of total carbonates with depth (Fig. 3), the high levels of $\mathrm{Mg}$ and $\mathrm{Ca}$ in the soil solutions (Fig. 6), and in the widespread occurrence of secondary carbonates at depth in all profiles. Differences in soil characteristics between the profiles described here can be related to differences in the extent to which dissolution has progressed and in the mineralogical composition of the carbonate parent material. Because the soils are of similar age, it is possible to relate the degree of dissolution to factors other than age.

Dissolution has been greatest at the Tønsneset site located in relatively lush Cassiope Zone vegetation. Carbonate parent material at Tønsneset is predominantly calcite, rather than the less soluble dolomite common at the other sites. A combination of higher soil $\mathrm{CO}_{2}$ levels, more abundant organic acids, and a more soluble and less abundant carbonate parent material is probably responsible for the greater decarbonation at Tønsneset than at the other sites. 
Table 6. Composition of representative soil solutions collected by tension lysimeters in Cannes and Arrigetch profiles, Kongsfjorden, Western Spitsbergen.

\begin{tabular}{|c|c|c|c|c|c|c|c|c|c|c|}
\hline \multirow[b]{2}{*}{ Horizon } & \multirow[b]{2}{*}{$\mathrm{pH}$} & \multirow[b]{2}{*}{$\mathrm{EC}(\mu \mathrm{S})$} & \multicolumn{4}{|c|}{ Anions (meq. $1^{-1}$ ) } & \multicolumn{4}{|c|}{ Cations (meq. $1^{-1}$ ) } \\
\hline & & & $\mathrm{HCO}_{3}$ & $\mathrm{SO}_{4}$ & $\mathrm{Cl}$ & $\mathrm{NO}_{3}$ & $\mathrm{~K}$ & $\mathrm{Na}$ & $\mathrm{Mg}$ & $\mathrm{Ca}$ \\
\hline \multicolumn{11}{|c|}{ Cannes profile $\mathrm{C} 7 / 22 / 83$ (irrigated with snow equivalent to approximately $30 \mathrm{~mm}$ rainfall over 4 days) } \\
\hline Irrigation snow & 6.34 & 3.0 & - & $<0.01$ & 0.02 & $<0.01$ & $<0.01$ & 0.02 & $<0.01$ & 0.01 \\
\hline Desert pavement & 6.68 & 5.3 & 0.10 & - & - & $<0.01$ & $<0.01$ & 0.03 & 0.03 & 0.03 \\
\hline A & 7.54 & 38.0 & 0.63 & $<0.01$ & 0.03 & $<0.01$ & 0.01 & 0.06 & 0.24 & 0.38 \\
\hline$B w l$ & 7.92 & 54.0 & 0.90 & $<0.01$ & 0.02 & $<0.01$ & 0.01 & 0.07 & 0.29 & 0.59 \\
\hline $\mathrm{C}$ & 8.03 & 76.0 & - & $<0.01$ & 0.03 & $<0.01$ & 0.01 & 0.12 & 0.47 & 0.75 \\
\hline \multicolumn{11}{|c|}{ Cannes profile $A 7 / 22 / 83$ (irrigated with water equivalent to approximately $28 \mathrm{~mm}$ rainfall over 4 days) } \\
\hline Irrigation water & 5.83 & 1.37 & $<0.01$ & $<0.01$ & $<0.01$ & $<0.01$ & $<0.01$ & $<0.01$ & $<0.01$ & $<0.01$ \\
\hline A & 7.35 & 17.0 & 0.27 & $<0.01$ & 0.01 & $<0.01$ & $<0.01$ & 0.02 & 0.11 & 0.16 \\
\hline Bwl & 8.08 & 140.0 & 2.23 & 0.02 & 0.14 & $<0.01$ & 0.02 & 0.24 & 0.82 & 1.36 \\
\hline $\mathrm{C}$ & 8.03 & 105.0 & 1.60 & 0.02 & 0.08 & $<0.01$ & 0.01 & 0.17 & 0.66 & 0.98 \\
\hline \multicolumn{11}{|l|}{$\begin{array}{l}\text { Groundwater } \\
\text { from Cannes }\end{array}$} \\
\hline Profilc B & 8.09 & 121.0 & 一 & 0.03 & 0.13 & 0.01 & 0.02 & 0.20 & 0.77 & 1.20 \\
\hline $\begin{array}{l}\text { Kvadchukelva } \\
\text { (stream water } \\
(2-24-83)\end{array}$ & 8.45 & 50.0 & 1.19 & 0.02 & 0.05 & $<0.01$ & 0.01 & 0.09 & 0.29 & 1.69 \\
\hline \multicolumn{11}{|c|}{ Arrigetch profile $A 8 / 6 / 81$ (irrigution water, equivalent to approximately $21 \mathrm{~mm}$ rain over 3 days) } \\
\hline $\mathrm{Oc}$ & 6.05 & 31.0 & - & 0.04 & 0.16 & 0.13 & 0.02 & 0.11 & 0.10 & 0.25 \\
\hline A & 4.63 & 37.2 & - & 0.02 & 0.01 & 0.01 & 0.01 & 0.09 & 0.05 & 0.16 \\
\hline $\mathrm{Bw}$ & 6.79 & 31.5 & 0.34 & 0.02 & 0.07 & 0.01 & 0.01 & 0.09 & 0.07 & 0.25 \\
\hline$c$ & 6.91 & 106.0 & - & 0.05 & 0.21 & 0.05 & 0.02 & 0.19 & 0.24 & 1.53 \\
\hline \multicolumn{11}{|c|}{ Arrigetch profile $B 8 / 10 / 84$ (irrigated with water, equivalent to approximately $21 \mathrm{~mm}$ rain over 3 days) } \\
\hline $\mathrm{Oc}$ & 6.73 & 17.5 & 0.18 & 0.02 & 0.06 & 0.03 & 0.01 & 0.09 & 0.06 & 0.18 \\
\hline A & 6.95 & 18.5 & 0.24 & 0.02 & 0.05 & $<0.01$ & 0.01 & 0.08 & 0.06 & 0.20 \\
\hline $\mathrm{Bw}$ & 7.46 & 41.0 & - & 0.04 & 0.12 & 0.03 & 0.01 & 0.12 & 0.12 & 0.41 \\
\hline $\mathrm{C}$ & 7.94 & 100.0 & 2.26 & 0.03 & 0.09 & 0.02 & 0.01 & 0.14 & 0.19 & 1.56 \\
\hline Stream water & - & - & 0.67 & - & - & - & 0.01 & 0.14 & 0.17 & 0.31 \\
\hline
\end{tabular}

The Spit and Mitra $\mathrm{C}$ sites exhibit the second most advanced stage of dissolution as evidenced by a deeper leaching of carbonate from the upper horizons than either of the other Polar Desert profiles (Cannes and Mitra B) (Fig. 3). For the Spit profile this greater degree of leaching is probably related to the slightly higher amount of soil organic matter present in the upper horizons and to its position close to the beach where sea spray may cause both higher precipitation and perhaps enhanced weathering by ocean-derived anions. The Mitra $C$ profile is similar to the Spit profile in degree of carbonate leaching despite its position further inland. Moreover, Mitra $\mathrm{C}$ is more leached than the Mitra $B$ profile, which has similar topographical position and vegetation. A possible explanation is that the Mitra $\mathrm{C}$ parent material was initially poorer in carbonates than either the Mitra B or Spit profiles, as indeed is suggested by pebble counts (Fig. 2). The Mitra B and Cannes profiles are roughly similar in degree of carbonate leaching despite the slightly lower content of carbonates in the parent material of Kapp Mitra.

The most obvious soil characteristic that can be related to this dissolution gradient is the development of the silt horizon. Although a striking feature of the Polar Desert profiles, silt horizons are missing from the Cassiope Zone profiles at Tønsneset beyond the presence of thin silt caps on stones. At Cannes, the silt in the thick Bwl horizon is predominantly dolomite; as is the very fine sand fraction (Fig. 5). As suggested by Forman \& Miller (1984), these dolomite-rich size fractions probably originate from the dissolution of calcite cement in dolomitic parent material in the upper horizons of the soil profile. Residual fine-grained particles, predominantly dolomite and detrital silicate minerals, are then washed down the profile (Wright \& Foss 1968; Boulton $\&$ Dent 1974) or perhaps moved down by frost 


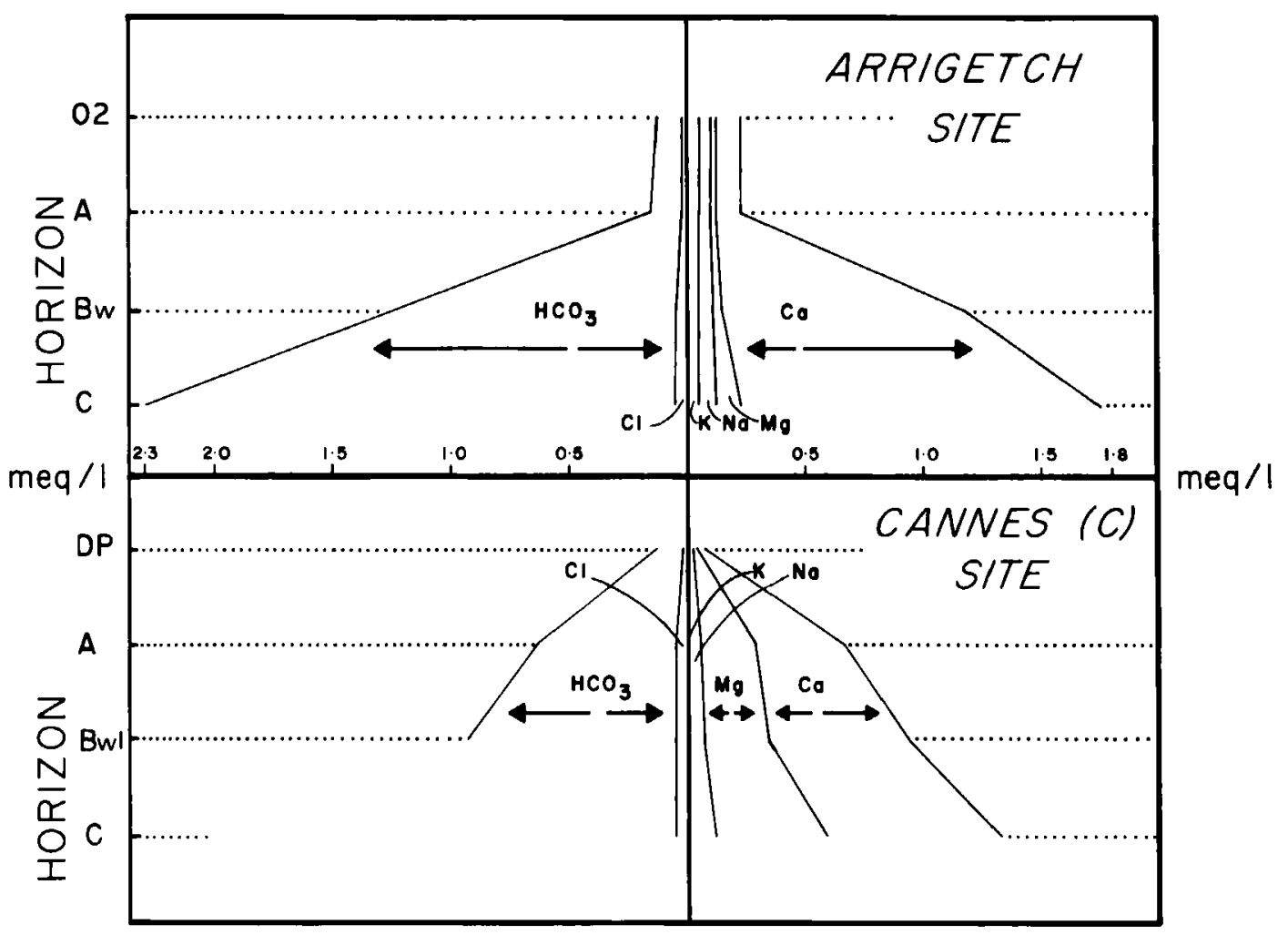

Fig. 6. Representative soil solutions from two Kongsfjorden. Spitsbergen, soil profiles collected by tension lysimetry following irrigation.

sorting (Bockheim 1979) to form the dense Bwl horizons. The Tønsneset profiles lack silt horizons because their primary carbonate minerals are highly soluble calcite rather than the more resistant dolomite and hence these profiles lack a supply of detrital, silt-sized particles. In addition, higher soil $\mathrm{CO}_{2}$ levels and abundance of organic acids leaching from the $\mathrm{Oi} / \mathrm{Oe}$ horizons would accelerate dissolution of what little dolomite might be present in the parent material.

Other soil properties that can be related to the extent of decarbonation are the vertical distributions of $\mathrm{Fe}$ and $\mathrm{Al}$ in the Kapp Mitra and Brøggerhalvøya soils (Table 5). Concentrations of $\mathrm{Fe}$ and $\mathrm{Al}$ tend to be highest in the upper horizons, above the zone of highest carbonate content, at the levels where dissolution presumably has been most intense. This trend holds for all but the Mitra B profile, where dithioniteextractable $\mathrm{Fe}$ and $\mathrm{Al}$ peak along with total carbonate in the Bwl horizon (Fig. 3 and Table 5). However, in the nearby Mitra $\mathrm{C}$ profile, $\mathrm{Fe}$ and
Al concentrations clearly occur above the zone of highest carbonates. Association of highest extractable $\mathrm{Fe}$ and $\mathrm{Al}$ concentrations with horizons of most intense decarbonation suggests these metals are the detrital byproducts of dissolution. Alternatively, they may be weathering out of primary silicate minerals. This possibility was tested by isolating and optically examining the heavy minerals from very fine sand fractions of the four horizons of the Arrigetch profile under the petrographic microscope. Unfortunately the more weatherable silicate minerals, such as pyroxenes and amphiboles, are absent from the parent material of this profile and weathering had to be assessed using the more resistant biotite grains. No clear evidence of weathering was detectable in any of the horizons based on comparisons between the biotite grains of the different horizons, except for the presence of reddish coatings on some biotite grains in the $\mathrm{Bw}$ horizons. These coatings could have originated through the initial stages in the weathering of the biotite, but 
more likely are byproducts of carbonate mineral dissolution.

Svalbard is composed largely of carbonate rocks (Orvin 1940) and the soils described here are probably typical of well-drained, Holocene aged soils of the archipelago. The soils of the Kongsfjorden area suggest that the decarbonation process plays a basic role in determining the pathway of soil development in a way analogous to the developmental sequences known from carbonate terrain at lower latitudes (Duchaufour 1982). As in the carbonate soils of other regions, weathering of silicate minerals is retarded by the swamping of the soil solution with ions derived from highly soluble, primary carbonate minerals. Formation of stable, humus-carbonate complexes may further slow weathering by reducing the activities of organic acids. Hence initiation of silicate mineral weathering is partly dependent on the preliminary dissolution of carbonate minerals. In Svalbard this preliminary decarbonation will be favoured in situations where carbonates are relatively scarce in the parent material and mainly in the form of calcite, and where vegetation is relatively lush. The continued presence of primary carbonates in the $\mathrm{BC}$ horizon at the Arrigetch site and the limited, if any, weathering of biotite grains in the $\mathrm{Bw}$ horizon there suggest that thorough decarbonation on Spitsbergen may take as much as 10,000 years, even under optimal conditions of Cassiope Zone vegetation and in parent material with less than $1 / 3$ carbonate content, largely in the form of calcite.

Decarbonation preliminary to silicate mineral weathering will proceed even more slowly in the soils whose parent materials contain more carbonate minerals than the Tønsneset sites, especially if dolomite is the dominant carbonate, and if vegetation is sparse. The soils developed on dolomitic, Polar Desert terrain in the Kongsfjorden area probably represent the most slowly decarbonating of Svalbard soils. In fact, soils developing in these dolomitic, Polar Desert areas around Kongsfjorden appear to be following a basically different developmental pathway than the Tønsneset type. Descriptions of soils developed on raised beaches on Brøggerhalvøya which may be older than the last interglacial (>120,000 years B.P.) (Forman \& Miller 1984) suggest that, with continued silt accumulation, small-scale frost heaving may circulate so much unweathered material through the surface horizons that thorough decarbonation is prevented, and pedogenesis, except for further silt production, is halted. Alternatively, as first suggested by Tedrow (1978), the gradual accumulation of silt may so alter moisture conditions that soil processes are overwhelmed by frost activities and the whole soil system is transformed to a periglacial one.

Acknowledgements. - This research was conducted under National Science Foundation Grant number DPP 8303624. We thank Steven Forman, Gifford Miller, Suzanne Prestrud, Bernard Hallet, and David Marrett for discussions regarding soil processes on Brøggerhalvøya. Ingvar Brattbakk and Olaf Rønning provided useful discussions on the vegetation and ecology of Svalbard. Kristian Sneltvedt and Grete Sneltvedt of Kings Bay Kull Company as well as Harold Gule and Howard Parker of the Norsk Polarinstitutt greatly assisted our logistics in Kongsfjorden. Randy Dahlgren, Richard Reanier, John Bethel, and Bevinea Lu helped with the laboratory analyses.

\section{References}

Akerman, J. H. 1983: Notes on chemical weather, Kapp Linné, Spitsbergen. Proceedings, Fourth International Permafrost Conference, 1983. National Academy Press, Washington D.C. $1524 \mathrm{pp}$.

Allison, L. E. 1965: Organic carbon. Pp. 1367-1396 in Black, C. A. (ed.): Methods of Soil Analysis. Publication number 9 in the series: Agronomy. American Society of Agronomy, Inc., Madison, Wisconsin. 1572 pp.

Blanck, E. 1919: Ein Beitrag Zur Kenntnis Arktischer Böden, insbesondere Spitzbergens. Pp. 421-476 in Linck, G. (ed.): Chemie der Erde l. Fischer, Jena.

Bockheim, J. G. 1979: Properties and relative ages of soils of southwestern Cumberland Peninsula, Baffin Island, N.W.T., Canada. Arctic and Alpine Research 11, 289-306.

Boulton, G. S. \& Dent, D. L. 1974: The nature and rates of post-depositional changes in recently deposited till from southeast Iceland. Geografiska Annaler 56A, 121-134.

Brattbakk, I. 1981: Brøggerhalvøya, Svalbard, Vegetasjonskart $1: 10,000$. K. norske Vidensk. Selsk. Mus Bot. avd. Trondheim, Norsk Polarinstitutt, Oslo 1980

Bundy, L. G. \& Bremner, J. M. 1972: A simple titrimetric method for determination of inorganic carbon in soils. Soil Science Society of America Proceedings 36, 273-275.

Challinor, A. 1967: The structure of Brøggerhalvøya, Spitsbergen. Geologists Magazine 104, 322-336.

Duchaufour, P. 1982: Pedology, Translated by T. R. Paton. George Allen \& Unwin, London, 448 pp.

Elvebakk, A. 1979: Plantesosiologi og -fenologi $i$ eit arktisk omrdde: Stuphallet, Brøggerhalvøya, Svalbard. Universitetet i Trondheim, $233 \mathrm{pp}$.

Federoff, N. 1966: Les sols du Spitsberg occidental. Spitsberg, 1964. Centre National de la Recherce Scientifique, Recherche Cooperative Programme 42 (Lyon), Ch. 10, pp. 111-228.

Fitzpatrick, E. A. 1960: Geomorphic notes from West Spitsbergen. Biuletyn Peryglacjalny 7, 49-54.

Forman, S. L. \& Miller, G. H. 1984: Time-dependent soil morphologies and pedogenic processes on raised beaches, Brøggerhalvøya, Spitsbergen, Svalbard Archipelago. Arctic and Alpine Research 16, 381-394. 


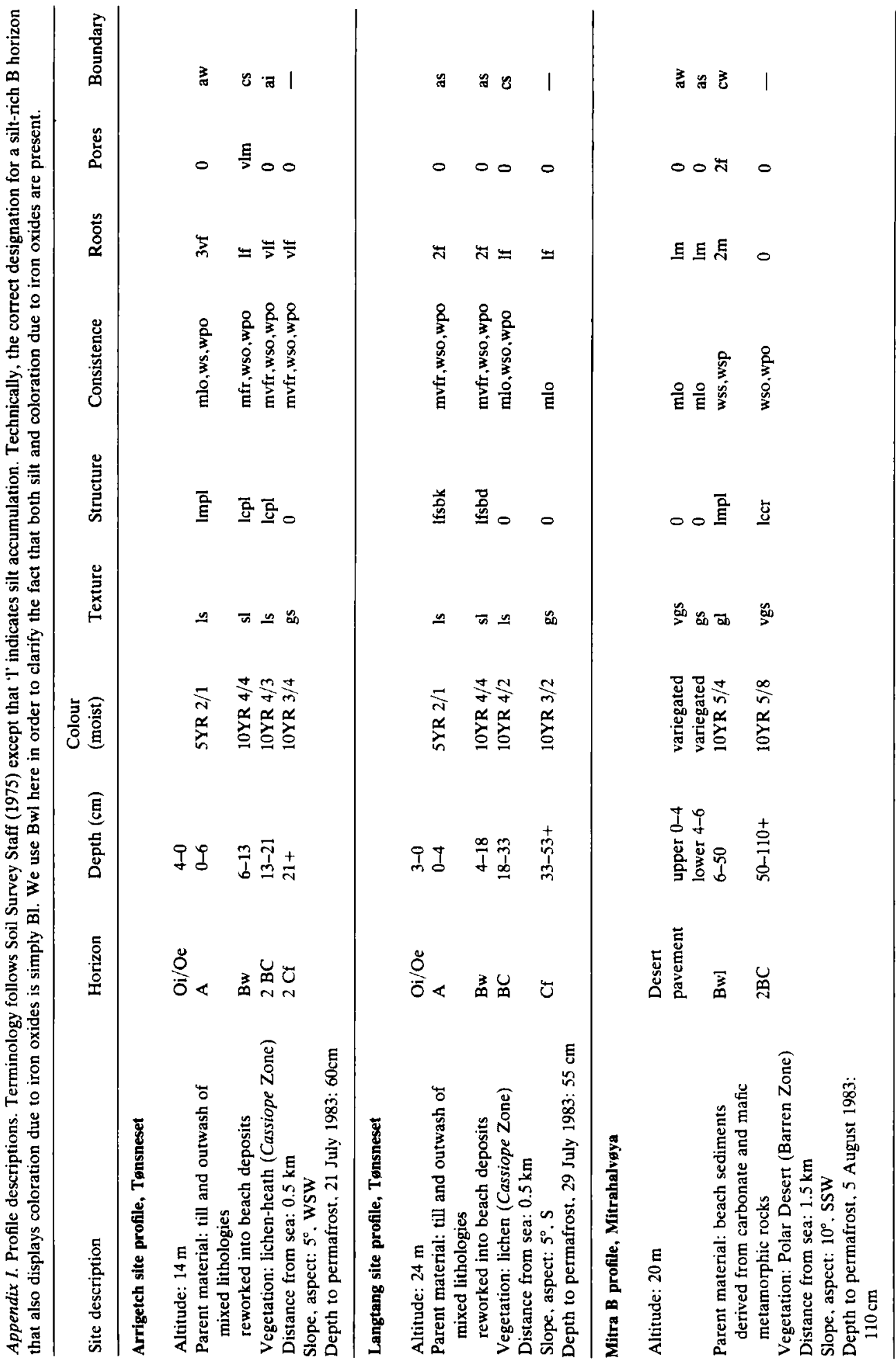




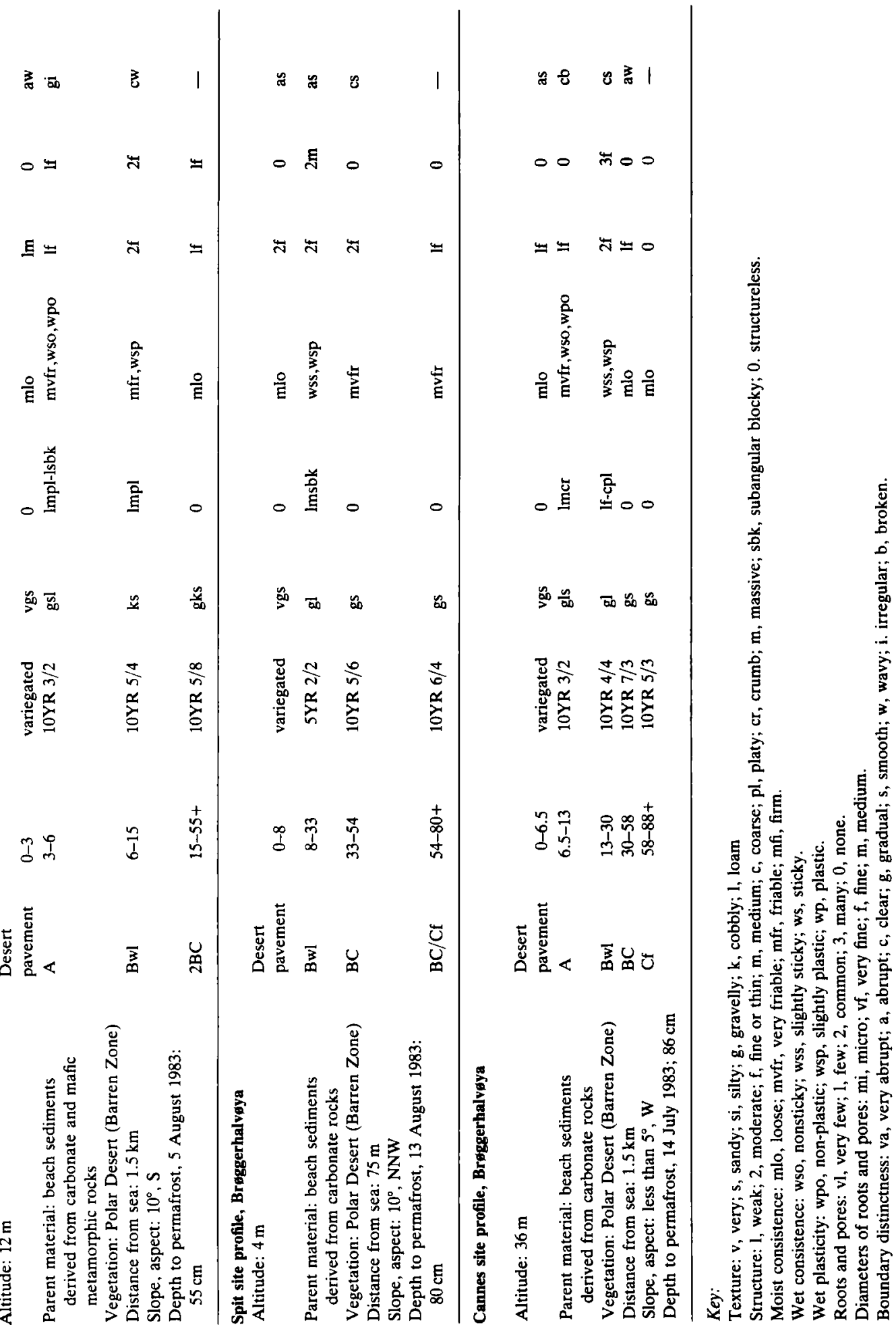


Guthrie, R. L. \& Witty, J. E. 1982: New designation for soil horizons and layers and the new soil survey manual. Comments and letters to the editor. Soil Science Society of America Journal 46, 443-444.

Hjelle, A. 1974: The geology of Danskøya and Amsterdamøya, northwest Spitsbergen. Norsk Polarinstitutt Skrifter 158, 738.

Hjelle, A. \& Lauritzen, Ø. 1982. Geological map of Svalbard $(1: 500,000)$. Sheet 3G, Spitsbergen northern part. Norsk Polarinstitutt Skrifter $154 C .15 \mathrm{pp}$. and map.

Jackson, M. L. 1969: Soil Chemical Analysis-Advanced Course. Department of Soil Science, University of Wisconsin, Madison, Wisconsin (published by the author). $895 \mathrm{pp}$.

Jahn, A. 1967: Some feature of mass movement on Spitsbergen slopes. Geografiska Annaler 49A, 213-225.

Mangerud, J. \& Gulliksen, S. 1975: Apparent radiocarbon ages of recent marine shells from Norway, Spitsbergen, and Arctic Canada. Quaternary Research 5, 263-274.

McKeague, J. A. 1967: An evaluation of $0.1 \mathrm{M}$ pyrophosphate and pyrophosphate-dithionite in comparison with oxalate as extractants of the accumulation products in Podzols and some other soils. Canadian Journal of Soil Science 47, 95-99.

Meindardus, W. 1930: Verteilung der Böden an der Erdoberffäche und ihre Ausbildung. pp. 27-96. in Blanck, E. (ed.): Handbuch der Bodenlehre, Vol. 3, pt. 1. Böden der Kalten Region, a) Arktische Böden. Springer, Berlin.

Orvin, A. K. 1940: Outline of the geological history of Spitsbergen, Norges Sualbard-og Ishavs-unders kelser Skrifter Nr. 78. $57 \mathrm{pp}$.

Parkinson, J. A. \& Allen, S. E. 1975: A wet oxidation procedure suitable for the determination of nitrogen and mineral nutrients in biological material. Communications in Soil Science and Plant Analysis 6, 1-11.

Polunin, N. 1945; Plant life in Kongsfjord, West Spitsbergen. Journal of Ecology 33, 82-108.

Rønning, O. I. 1965a: Studies in Dryadion of Svalbard. Norsk Polarinstitutt Skrifter $134.51 \mathrm{pp}$.

Rønning, O. I. 1965b: Features of the ecology of some Arctic Svalbard (Spitsbergen) plant communities. Arctic and Alpine Research 1, 29-44.
Salvigsen, O., Lauritzen, $\emptyset$. \& Mangerud, J. 1983: Karst and karstification in gypsiferous beds in Mathiesondalen, Central Spitsbergen, Svalbard. Polar Research 1, 83-88.

Smith, J. 1956: Some moving soils in Spitsbergen. Journal of Soil Science 7, 10-23.

Soil Survey Staff, 1962: Supplement to Agricultural Handbook 18 (replacing pp. 173-188 of Soil Survey Manual). U.S. Government Printing Office, Washington, D.C.

Soil Survey Staff, 1975: Soil taxonomy: a basic system of soil classification for making and interpreting soil surveys. Agriculture Handbook 436. Soil Conservation Service, U.S. Department of Agriculture, U.S. Government Printing Office, Washington, D.C. $554 \mathrm{pp}$.

Soil Survey Staff, 1981: Soil Survey Manual, Chapter 4 of Agricultural Handbook 18. U.S. Government Printing Office, Washington, D.C. 105 pp.

Steffensen, E. L. 1982: The climate at Norwegian arctic stations. Klima 5. 44 pp.

Summerhayes, V. S. \& Elton, C. S. 1928: Further contributions to the ecology of Spitsbergen. Journal of Ecology 16, 193268.

Szerszen, L. 1968: Preliminary investigations of soil cover in the region of Hornsund, Vestspitsbergen. Pp. 217-227. in Birkenmayer, K. (ed.): Polish Spitsbergen Expeditions 19571960, Polish Academy of Sciences, Warsaw.

Tedrow, J. C. F. 1977: Soils of the Polar Landscape. Rutgers University Press, New Brunswick, New Jersey. 638 pp.

Tedrow, J. C. F. 1978: Development of Polar Desert soil. Pp. 413-425 in Mahaney, W. C. (ed.): Quaternary Soils. Geo. Abstracts., Norwich, England. 508 pp.

Ugolini, F. C., Zachara, J. M. \& Reanier, R. E. 1982: Dynamics of soil-forming processes in the Arctic. Proceedings of Fourth Canadian Permafrost Conference; Calgary Alberta, 103-115. van Vliet-Lanoe, B. 1983: Etudes cryopedologiques au sud du Kongsfjord, Sualbard. Publication Interne du Centre de Geomorphologie du Centre National de la Recherche Scientifique. 39 pp.

Wright, W. R. \& Foss, J. E. 1968: Movement of silt-sized particles in sand columns. Soil Science Society of America Proceedings 32, 446-448. 